DOI: https://doi.org/10.18371/fp.3(35).2019.190081

JEL Classification G21

\title{
DEVELOPMENT OF BANK INNOVATIONS IN KAZAKHSTAN UNDER THE CONDITIONS OF FUNCTIONING OF THE EAEU
}

\section{GRIDNEVA Yelena}

Candidate of Economic Sciences, professor «Kainar» Academy

Republic of Kazakhstan, Almaty

ORCID ID: https://orcid.org/0000-0002-3279-2036

e-mail: elengred@mail.ru

\section{KALIAKPAROVA Gulnar}

PhD, Associate Professor «Kainar» Academy

Republic of Kazakhstan, Almaty

ORCID ID: https://orcid.org/0000-0002-1859-9774

e-mail:GK_2003@rambler.ru

\author{
ALPYSBAYEV Kaisar \\ Senior Lecturer «Kainar» Academy \\ Republic of Kazakhstan, Almaty \\ ORCID ID: https://orcid.org/0000-0003-3349-701X \\ e-mail:kaisaralp@gmail.com
}

\begin{abstract}
In the context of globalization, the issue of introducing and developing innovations in the banking sector is a modern and complex process. Innovative technologies make it possible to increase the image and financial independence of the bank. In this direction, EAEU countries have great experience in conducting scientific and technical cooperation and pursuing innovative policies, which in the future can become full partner countries for Kazakhstan. In the article, the authors identify the reasons for the emergence of new banking technologies, reveal the main ways of developing banking innovations in Kazakhstan in the conditions of the EAEU. The authors proposed a new interpretation of banking innovation.

Keywords: Kazakhstan, banks, second-tier banks (STB), banking, innovation, banking innovation, integration processes, EAEU, scientific and technological progress (STP).
\end{abstract}

Аннотация. $B$ условиях глобализации проблема внедрения и развития инноваций в банковском секторе является современным и сложным процессом. Инновачионные технологии позволяют повысить имидж и финансовую независимость банка. В этом направлении странь ЕАЭС имеют большой опыт в проведении научно-технического сотрудничества и проведении инновачионной политики, которые в перспективе могут стать полноправныли странами-партнерами для Казахстана. Для нашей страны важно вхождение в мировое сообщество, совершенствуя техническую и инновационную ба3у. Авторы предложили новую интерпретацию банковских инновачий.

Ключевые слова: Казахстан, банки, банки второго уровня (ВБУ), банковская сфера, инновации, банковские инновачии, интеграционные прочессы, ЕАЭС, научнотехнический прогресс (НТП). 
Problem statement. Banks are evolving under the influence of globalization factors. In modern conditions, any bank tries to implement banking innovations and offer the latest non-standard, multivariate services, products, processes and technologies, devices, new financial instruments, new forms of business that can improve their efficiency and enhance competitiveness.

At the same time, the insufficient level of scientific research in this direction does not allow banks to respond to changes in the real sector of the economy immediately. Therefore, a comprehensive study of theoretical and practical issues of innovative technologies in the activities of second-tier banks in the context of integration processes is relevant.

\section{Literature Review and Prob-} lem Statement. Theoretical foundations of the study of innovations and innovative processes were laid by the works of such scientists as: J. Schumpeter, B. Twiss, G. Mensh, N.D. Kondratiev, H. Freeman, L. Medynsky, S.Yu. Glazyev, B. Santo, V.S. Utkin, R.A. Fathutdinov and others.

Among the scientific publications that are devoted to problematic issues of banking management strategy and innovative activity, the development of directly innovative technologies and business processes in banks, the works of L.V. Koch, O.I. Lavrushin, L.P. Belykh, N.A. Kravchenko, Peter S. Rose, D. Simonson, G. Mason and others can be mentioned. Problems of introducing innovations in Kazakhstan were investigated by F.G. Alzhanova, R.A. Alshanov, A.A. Arupov, U. Baimuratov, K.S. Bay- sholanova, F.M. Dnishev, A.S. Zharkynbaeva, A. Toksanova and others.

It should be noted that among the numerous publications devoted to devoted to the development, adoption and distribution of banking innovations, little attention was paid to the justification of the importance of their implementation in the banking system of Kazakhstan. It plays one of the main roles in the development of the country's economy, in the conditions of the functioning of the Eurasian Economic Union (EAEU), given the prospects and not excluding possible problems.

Purpose of article. To identify the main development paths and features of the introduction of modern innovative technologies in the domestic banking sector in the conditions of the EAEU functioning.

Results of the Research. The presidents of five countries - Russia, Belarus, Tajikistan, Kazakhstan and Kyrgyzstan, within the framework of integration, established the EurAsEC in accordance with the Agreement of October 10, 2000, signed by these countries. The aim of the creation of the EurAsEC was to form a clear organizational and legal structure which would ensure the mandatory implementation of all decisions taken on the performance of joint innovative projects. Later, after fourteen years, the EurAsEC was abolished and transformed into the EAEU (Eurasian Economic Union) from January 1, 2015, which included Russia, Belarus, Armenia, Kazakhstan, Kyrgyzstan [1].

EAEU assumes integration within the framework of a single economic space and a single customs territory, the main points of which are: abolition of customs 
duties for participants in mutual trade in goods; introduction of common customs tariffs; development of economic restrictions with the exception of special anti-dumping and countervailing measures; other regulatory measures on trading with third parties [2, p. 26].

The EAEU countries are characterized by the fact that each of it individually is not competitive in most areas of economic activity due to lack of advanced research areas, inability to provide hightech modernization of the real sector of the economy and unpreparedness of some industries for innovative processes in the economy, including banking sector.

Banks are one of the most difficult areas of business due to the specifics of the organizational structure and variety of functions [3, p. 3]. Banking products and services provided by banks of the EAEU countries have a certain similarity. Thanks to the adoption of innovative strategies by banks, in the banking sector, more and more offers of banking innovations - innovative services and products based on modern information and communication technologies, can be seen. In turn, this determined the development of innovative business in banks as a separate business model for increasing the efficiency of operational activities, expanding the client base and strengthening the position in the banking services market.

For the development of innovative processes in the banking sector, it is important to determine correctly the essence of the concept of "banking innovation", which is ambiguously interpreted today.

$\mathrm{O}$.V. Ivanova gives the following definition: "Banking innovation is the End result of innovation activity, a specific type of financial innovation implemented by banks in the financial markets or in their own activity in the form of a new or improved banking product, service, process, organizational form or technology with the aim of more efficient formation and placing the resource potential of a commercial bank" [4, p. 7].

O.I. Lavrushin defines the concept of "banking innovation" as synthetic regarding the purpose and results of the bank. At the same time, the scientist emphasizes the fundamental novelty and the possibility of the multiple nature of innovation. Considering banking innovation, O.I. Lavrushin notes that its development and offer on the market is aimed at obtaining additional income by the bank, assisting customers in making profits through the innovative activities of banks, namely, "in the process of creating favorable conditions for the formation and deployment of resource potential through the introduction of innovations" [5, p. 23].

D.N. Ternovsky gives the following definition: "Banking innovations are the results of banking activities that are aimed at generating additional income both in tangible and intangible form, during the development and distribution of resources in parallel with innovations that would help preserve and increase the capital of bank customers" [6, p. 4].

P.V. Semikova says that banking innovation is the end result of innovative banking, which is developing in the form of a new banking product or service [7, p. 37].

In the big economic dictionary, it is noted that when using banking innovations, methods are used to conduct trans- 
actions with new financial assets, or new operations with current assets, allowing to increase the effect of using financial resources of organizations [8, p. 138].

In our opinion, based on the foregoing, the following definition of banking innovation will be correct. Banking innovation -is an improvement, or the introduction and successful development of modern innovations in the banking sector, contributing to the stimulation of innovative activity, ensuring the competitiveness of the bank, maximizing profits and meeting customer needs, considering the scientific and technological progress (STP).

By developing and implementing innovative technologies in the banking sector, as in other sectors of the economy, we often rely on world experience and see how banking systems are developing in other countries. We note both positive and negative experiences. Practice shows that: 1) banking products and services are recognized as innovations only when the relevant patents are issued; 2) introduced innovations are quickly distributed among competing banks.

For the banking system of Kazakhstan, it is important not only the implementation of foreign experience, but also the introduction of its own innovative developments. It also should be noted that not always the positive experience gained in one country can lead to the same positive in another. Thus, it can be connected with regulatory framework established in the state, the unpreparedness of the population to introduce new banking products, that is, innovations are not always accepted and understood correctly. For example, such experience was with the introduction of payment cards, when the majority of the population didn't have clear idea whether there was money on the cards. It was more common to have money in cash when you see it and can feel it. In addition, innovative banking products and services that have received widespread support in other countries do not show the same degree of adoption and distribution in the country that implements them. In other words, the blind introduction of foreign banking services and products does not always lead to the best expected result [9, p.26].

Within the framework of the EAEU, in order to develop financial policy, it is planned to concentrate efforts on creating a common financial market, creating conditions for mutual recognition of licenses in the banking, insurance and securities markets, and ensuring nondiscriminatory access to the national financial markets of the EAEU states [15, p. 85]. In turn, this implies a clear understanding of the functioning of national financial markets and systems for their further harmonization with common international principles and standards.

Among the priority areas that require concerted action, the formation of monetary and foreign exchange mechanisms to ensure financial stability and economic growth within the framework of the EAEU integration processes, should be mentioned. In particular, the implementation of blockchain and cryptocurrency technologies deserves special attention. Their implementation requires the need to regulate and balance the possible risks and new opportunities. With all the difficulties with the introduction of new financial instruments and products, radically change the model of the financial market becomes to be possible. 
Mutual cooperation is important in the field of development and integration of national payment systems of the EAEU member states, including the introduction of modern technologies and standards in payment systems [15, p. 49].

In the banking systems of the EAEU member states, payment systems demonstrate the greatest invasiveness.

By the development of new innovative electronic banking technologies in the banking sector in Russia, changes are observed in the bank-client system. An example is the development of remote banks, otherwise called self-service banks, where the use of financial services occurs via the Internet. In addition, the bank's client has the opportunity to receive information or use the services via email, social networks or the bank's website. An additional advantage of the development of innovative retail payment instruments is the reduction of the time gap associated with the attraction and allocation of resources, which determines the speed of economic development, because the bank is an intermediary between entities that own temporary free funds and entities that need these free monetary resources [10, p. 125].

The National Bank of Belarus recommends that the banks operating in the country gradually switch to the introduction and development of new banking products and services, thereby expanding their access to the global market of electronic banking technologies. Such proposals are primarily associated with an assessment of the activities of the $\mathrm{Na}$ tional Bank. Opportunities for growth are minimal in the classical banking market with typical traditional products and services, since over the past 5-10 years, the growth rate of the country's banking system has significantly outpaced the economic growth rate in Belarus. The opportunities of Belarusian banks are associated with an increase in the turnover of payment bank cards, an increase in noncash payments, an increase in the relationship of banks with mobile operators, the development of an electronic money system, and the creation of necessary new products and services using computer technologies in banking practice. It is necessary to mention new opportunities for Belarusian banks with Kazakh and Russian within the framework of the Common Economic Space. The banking system of Belarus has excellent prospects, which are based on the availability of a good university and academic school, the developing traditions of the production of electronic computers and the success of the High-Tech Park, most of which create and develop such software products and technologies on the international market that contribute to the development of electronic economics and electronic banking [11].

Due to the intensified development of the banking system of Armenia, the intensive growth of competition, Armenian banks are trying to diversify the banking market, search for vacant niches, expand the list of banking services. The intensive development of remote banking technologies leads not only to replenishing the list of services already offered, but also to a new strategically necessary area of activity. According to the expert forecasts, the development of the banking business through electronic technologies has become one of the main trends in the banking market of Armenia. According to the experts, this advancement may turn 
into the most long-term strategy. It is with the help of electronic technologies that the future development of modern banking technologies will be determined. The development of Internet banking in Armenian banks is a young area, unlike the EAEU countries. Creation of Internet banking makes it possible to improve customer service, improve current business processes, that increase the speed of operations and the quality of service, opening up opportunities for expanding new services. Due to the relatively high level of Internet equipment in Armenia, as well as the availability of the necessary equipment, we noted that the banking system of Armenia is ready to continue the development of online services. Armenian banks pay special attention to the development of Internet commerce, in connection with which the VISA Internet acquiring project was introduced. For convenience, simplification and increase the speed of the process of entering data and setting up internet sites for card payments, the software tool vPOS/virtual POS was created and implemented. The vPOS/virtual POS software tool enables websites to make payments quickly using VISA, MasterCard and $\mathrm{ArCa}$ cards, minimizing time and other resources for programming, configuring and testing such services.

Nowadays, the vPOS/virtual POS software tool is an active project with positive dynamics. There is the developing additional services for vPOS in the process, due to which Internet sites will have new opportunities for customers [12].

In the 1st quarter of 2019, 28 secondtier banks (STB) performed their work on the banking market of Kazakhstan
[13]. It should be noted that not all banks are able to be competitive, as not everyone tries to develop its own innovative banking services and products, content with offering slightly improved traditional options. The reasons for this low innovation activity are problems observed in the banking sector of our republic, for example, such as:

due to the uneven development of economic sectors, leading to different incomes, banks tend to give out more consumer loans than investment loans;

- inflationary processes taking place in the country require the issuance of longer money, as the growth in longterm loans from the population has grown significantly;

fear of losing the established large customers of the bank leads to a lack of desire to introduce and expand new products and services, which, in turn, leads to the opening of these customers several credit lines or accounts in different banks;

there are cases, when a bank cannot finance large corporations because of the inability to organize the distribution of its own resources, clients have to wait a few days, which leads to a weakening of confidence in the bank;

errors in retail funding in the absence of a market for redistribution of liquidity, as well as the underdevelopment of the refinancing system, which leads to qualitative and temporary inconvenience in the lending process;

- search for new methods to deal ATM fraud;

an increase in the share of problem loans that negatively affect the economy, thereby complicating the process of 
revitalizing the macroeconomic environment;

presence of a difference in the amounts of assets and liabilities of currencies in the banking sector, due to an increase in consumer preferences over the national currency, while banks - over foreign;

heterogeneous development of cross-selling by each bank, which leads to the "freezing" of certain products and services of the bank.

One of the latest innovations in the banking system of Kazakhstan was the assembly of biometric ATMs by Kazakhstani company iMoney, which develops hardware and software solutions. Such implementation will give an important social effect as it can provide financial inclusion for people with disabilities. Such innovative services that provide integration of banking services with social networks, use geolocation data, as well as the creation of virtual branches, are becoming increasingly widespread on the market. All this will allow Kazakh banks to improve their current activity on the provision of banking products and services, thereby keeping pace with the times, improve the quality of services and strengthen trust among customers, minimize risks and costs, maximize profits.

Conclusions. In the conditions of the EAEU, the development of the banking system of Kazakhstan should be based on the active introduction of banking innovations, for which, in our opinion, it is necessary:

to form at the state level the Concept of strategic innovation management in banks [13, p. 126]; to develop the high-quality remote banking services, as a fundamentally new level of service for large corporate clients and a competitive advantage in the provision of banking services, as well as an effective mechanism for the interaction of banks and various structures;

- $\quad$ to adhere to the principle of technological interdependence, that is, sharing the increasing costs and risks of innovations, and concentrating the right amount of skills and experience when introducing innovations within the framework of global networks between participants in innovation processes and their representatives;

to develop the open innovation, to wit the strengthening of interstate integration of universities and banking institutions, in other words, cooperation and financing by universities and large companies of commercial common results;

- to provide training for specialists of banking innovations and their promotion on the market, to introduce the information technology in the bank management system and business process models;

- to stimulate the innovations within a banking institution, expanding the intraorganizational base of technologies and ideas;

to create the innovation centers operating on the basis of commercial banks (instead of the Department for the Development of Innovative Products and Services), which will include the entire service from development to offering the product / service to the consumer, turning into part of the cross-sales [13, p. 134].

Thus, within the framework of the EAEU, it is planned to form a single 
economic space, and among the tasks assigned, it is possible to admit and remove all barriers that impede the full functioning of bank branches and financial organizations throughout its territory. On the one hand, this can be noted as many new opportunities, and on the other, as new challenges for national banking systems and each individual bank of the EAEU member states, including Kazakhstan. Only the active introduction of banking innovations can help to overcome negative trends, remain competitive and prevent the dominance of Russian banks and their absorption of smaller and less competitive banks in the financial markets of the EAEU member states under a single banking license.

\section{References}

1. Yevraziyskiy ekonomicheskiy soyuz: stanovleniye, razvitiye, znacheni [Eurasian Economic Union: formation, development, values]. eurasian-studies.org. Retrieved from: http://eurasian-studies.org/archives/3267 [in Russian].

2. Gridneva, Ye.E. (2018). Kazakhstan v sisteme mezhdunarodnoy ekonomiki [Kazakhstan in the system of international economy]. Almaty: Kainar Academy [in Russian].

3. Irishev, B.K. \& Imramziyeva, M.Ya. (2015). Internet - marketing kak tekhnologiya prodvizheniya $\mathrm{v}$ kommercheskikh bankakh [Internet marketing as a promotion technology in commercial banks], Sovremennoye sostoyaniye $i$ prioritetnyye napravleniya razvitiya marketinga: materialy mezhdunarodnoy nauchno prakticheskoy konferentsii - Current state and priority directions of marketing development: materials of the international scientific and practical conference. Almaty, 37 [in Russian].

4. Ivanova, O.I. (2011). Bankovskiye innovatsii $i$ napravleniya ikh razvitiya $v R F$ [Banking innovations and their development directions in the RF]. Extended abstract of $\mathrm{PhD}$ thesis. Kuban State University [in Russian].

5. Lavrushin, O.I. (2019). Regulyativnyye innovatsii v bankovskom sektore $i$ ikh razvitiye $v$ interesakh natsional'noy ekonomiki [Regulatory innovations in the banking sector and their development in the interests of the national economy]. Moscow: KnoRus [in Russian]. 
6. Ternovsky, D.N. (2012). Innovatsionnyye bankovskiye produkty v kreditovanii malogo i srednego biznesa [Innovative banking products in lending to small and medium-sized businesses]. Extended abstract of $\mathrm{PhD}$ thesis. Nizhny Novgorod State University [in Russian].

7. Semikov, P.V. (2008). Bankovskiye innovatsii i novyy bankovskiy produkt: Bankovskiye tekhnologii [Banking Innovation and the New Banking Product: Banking Technology]. Moscow: Yurait [in Russian].

8. Borisova, A.B. (Ed). (2003). Bol'shoy ekonomicheskiy slovar' [Big economic dictionary]. Moscow: Kniznyi mir [in Russian].

9. Orlovsky, V. (2010). Innovatsiy na vyrost [Growth Innovation]. Banking technology, 3, 26-29 [in Russian].

10. Imramziyeva, M.Ya. (2014). Neobkhodimost' razvitiya innovatsionnykh tekhnologii v kommercheskikh bankakh stran YeAES [The need to develop innovative technologies in commercial banks of the EAEU countries]. Problemy i perspektivy industrial'no- innovatsionnogo razvitiya $v$ Yevraziyskom ekonomicheskom soyuze (YeAES): materialy mezhdunarodnoy nauchno - prakticheskoy konferentsii - Problems and prospects of industrial and innovative development in the Eurasian Economic Union (EAEU): materials of the international scientific and practical conference. Karaganda: KEUK, pp. 355-359 [in Russian].

11. Natsbank Belarusi prizval banki strany ne zhdat' smyagcheniya protsentnoy politiki i aktivno razvivat' novyye rynki i servisy [The National Bank of Belarus called on the country's banks not to wait for the easing of interest rate policy and to actively develop new markets and services]. belta.by. Retrieved from: http://www.belta.by/ru/all_news/economics [in Russian].

12. Udalennyye bankovskiye uslugi dlya tekh lyudey, kto cenit svoye vremya. [Remote banking services for those who value their time]. panarmenian.net. Retrieved from: http://www.panarmenian.net/rus/interviews/183159/ [in Russian].

13. Reyting bankov Kazakhstana po versii Kursiv. Itogi pervogo kvartala 2019 goda [Rating of banks of Kazakhstan according to Kursiv. Results of the first quarter of 2019]. kursiv.kz. Retrieved from: https://kursiv.kz/news/tendencii-iissledovaniya/2019-05/reyting-bankov-kazakhstana-po-versii-kursiv [in Russian]. 
14. Imramzieva, M. Ya. Innovatsionnyye tekhnologii $v$ deyatel'nosti bankov vtorogo urovnya. [Innovative technologies in the activities of second-tier banks]. Ph.D thesis. University of Turan. [in Russian].

15. Finansovaya politika $\mathrm{v}$ ramkakh Yevraziyskoy integratsii. Retrieved from: http://www.eurasiancommission.org/ru/Documents/EEC_finpolit_150629_2.pdf [in Russian]. 